Biljana M. Đukić' , Maja N. Račić

Jelena R. Pavlović2, Biljana P. Mijović2

Health Center Banjaluka, Bosnia and Hercegovina ${ }^{1}$

Faculty of medicine Foca, University in Eastern Sarajevo, Bosnia and Hercegovina ${ }^{2}$

\section{IIIness perception and treatment adherence in patients with chronic heart failure and sideropenic anemia}

\section{Key words:}

heart failure, sideropenic anemia, illness perception, adherence

\section{Abstract}

Objective: The primary aim of this study was to examine whether the perception of the patient's disease and adherence to treatment process influence treatment outcomes of heart failure. The secondary aim was to analyze whether there were differences in perception and adherence in patients with heart failure in relation to anemia.

Method. A cross-sectional study was carried out in 2015. One group consisted of 100 patients with heart failure and sideropenic anemia. The other group consisted of 100 patients without anemia. The standardized questionnaire was used to collect demographic data, the Brief Illness Perception Questionnaire to measure the patients' perception of the disease and modified Clinician rating scale to assess patient' $s$ adherence.

Results: The majority of respondents in the first group were women - $63 \%$, while in the second group there were $58 \%$ male and $42 \%$ female respondents. Respondents from the first group had statistically significantly lower adherence compared to respondents from the second group $(\chi 2=23.28$; $\mathrm{p}=0.05)$. A significant difference was found between the groups of subjects in comparison to the perception of disease control $(\chi 2=18.03 ; \mathrm{p}=0.05)$.

Conclusion: The illness perception and treatment adherence have a significant impact on treatment outcomes of heart failure. Comorbidities, such as anemia, contribute to the patients' perception of their disease and influence their adherence. 


\section{Introduction}

In the cardiovascular continuum chronic heart failure (HF) represents the final stage of all cardiovascular diseases, regardless of whether it is ischemic, hypertensive, valvular or immuno-infected. Hospitalization rates, post-discharge mortality and readmission rates are still very high despite the improved treatment options; ultimately leading to high consumption of healthcare resources in developed as well as in developing countries ${ }^{1}$.

Previous studies found that health - related quality of life, as a treatment outcome, is deteriorated in heart failure ${ }^{2}$, particularly when associated with comorbidities ${ }^{3,4,5}$.Anemia is very common in heart failure, especially in hospitalized patients, females, elder people and those with renal insufficiency. An erythropoietin inhibition occurs on two levels: the kidneys and the bone

marrow have the biggest role in the onset of anemia in heart failure. The damaged myocardium in heart failure produces increased amounts of cytokine tumor necrosis factoralfa, which inhibits the effect of erythropoietin on the progenitor cell of the red blood cell, due to which it prevents the release of iron from the reticuloendothelial system and reduces the hemoglobin synthesis ${ }^{6}$. Anemia may lead to the worsening of heart failure and decline of health-related quality of life of patients suffering from heart failure ${ }^{4}$.

The perception of disease represents a patient's cognitive belief about their disease, and it signifies important determinant of behavior and results in numerous outcomes that are important for the patient's cooperation and functional recovery. Illness perception is also important for clinician in order to understand what kind of beliefs a person has (whether ethical, social or religious), how disease affects patients' everyday life (a relationship with family, friends), or how much a person is able to control the disease (does the disease control a person or a person controls the disease) ${ }^{7}$. Identification of patients' beliefs and behavior plays an important role in the treatment and education of patients with $\mathrm{HR}^{8}$. However, data on the association of illness perception and treatment outcomes in patients with heart failure and associated anemia are lacking.

The primary aim of this study was to examine whether the perception of the patient's disease and adherence in the treatment process influences treatment outcomes of heart failure. The secondary aim was to analyze whether there are differences in perception and adherence in patients with heart failure in relation accompanying anemia.

\section{Method}

\section{Study participants}

A cross-sectional study was carried out at the Department of Cardiology, Clinical Center Banja Luka, Bosnia and
Herzegovina, from April to September 2015. Eligible patients were men and women, 18 years of age or older, outpatients, with symptomatic chronic heart failure and New York Heart Association (NYHA) functional classes III and IV at time of enrolment. Another enrolment criterion was left ventricular ejection fraction (LVEF] $\leq 45 \%$ measured by echocardiography. The diagnosis of heart failure was made by experienced cardiologists. The patients were further divided into two groups. One group consisted of 100 consecutive patients with heart failure and associated anemia, and the other group of 100 consecutive patients with heart failure but without anemia. Patients were excluded if they were unable to complete the questionnaires, had undergone intervention within the last 6 months, experience symptoms for which hospitalization was considered necessary and had chronic liver disease or pericardial disease.

\section{Instruments}

The standardized questionnaire was used to collect sociodemographic data about the study participants.

The Brief Illness Perception Questionnaire (IPQ) measured the patients' perception of the disease ${ }^{9}$, included 8 items, evaluating the perception on a 0-10 response scale. Five items analyzed cognitive aspects, such as identity, personal control, treatment control, consequences, and timeline. Questions numbered six and seven focused on concerns and emotions, and question eight on illness comprehensibility. Separate item was an open-ended question on the three most important causal factors of their illness. The higher the score, the more person felt endangered by the illness.

To evaluate treatment adherence, the researchers asked all patients to complete a Clinical rating scale (CRS). The scale encompassed 7 questions with dichotomous answers (YES or NO) and one question on how often the patient did not take his medications. According to the overall score, the adherence was categorized as low $(<5)$, intermediate (5-6) and high (7). Higher numbers represent greater adherence ${ }^{10,11}$.

Treatment outcomes assessed, included the Likert scale for dyspnea and fatigue, analysis of number and length of hospitalization, the presence of peripheral edema, 24-hour measurement of blood pressure, levels of CRP, sedimentation rate (ESR), hemoglobin, hematocrit, iron, TIBC, and ferritin values.

\section{Statistical analysis}

Statistical analysis was performed using the v22 SPSS package. Numbers and percentage for categorical variables were used to describe clinical outcomes, treatment adherence, and illness perception. The linear correlation between the variables was analyzed with Pearson correlation coefficient. Statistically significant difference was evaluated by application of $\chi 2$ square test. P-value level $<0.05$ was considered significant. 


\section{Ethical Considerations}

All participants gave informed consent. Data are presented in a manner that conceals the participants 'identities.

\section{Results}

The majority of study participants in the group with anemia (G1) were females (63\%) and in the group without anemia (G2) males $(58 \%)(\mathrm{p}=0.012)$. A statistically significant difference between the groups was not found, by age and used medications. Majority of participants in both groups had 1-2 hospitalizations per year $(\mathrm{p}=0.006)$, however, most of the participants in group 2 spent more than 6 weeks in hospital $(\mathrm{p}=0.003)$, (Table 1).

Table 1. Demographic characteristics of the study participants Табела 1. Демографске карактеристике испитаника

\begin{tabular}{|c|c|c|c|}
\hline Variable & $\begin{array}{c}\text { Group } 1 \\
\%\end{array}$ & $\begin{array}{c}\text { Group } 2 \\
\%\end{array}$ & p \\
\hline $\begin{array}{c}\text { Gender } \\
\text { Male } \\
\text { Female }\end{array}$ & $\begin{array}{l}37 \\
63\end{array}$ & $\begin{array}{l}58 \\
42\end{array}$ & 0.012 \\
\hline $\begin{array}{l}\text { Age } \\
25-44 \\
45-59 \\
60-74 \\
>75\end{array}$ & $\begin{array}{c}5 \\
23 \\
38 \\
34\end{array}$ & $\begin{array}{c}1 \\
31 \\
44 \\
24\end{array}$ & 0.156 \\
\hline $\begin{array}{c}\begin{array}{c}\text { Number of hospitalizations } \\
\text { per last year } \\
<1 \\
1-2 \\
>3\end{array}\end{array}$ & $\begin{array}{c}46 \\
52 \\
2\end{array}$ & $\begin{array}{c}14 \\
83 \\
3\end{array}$ & 0.006 \\
\hline 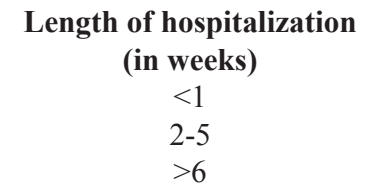 & $\begin{array}{l}21 \\
52 \\
27\end{array}$ & $\begin{array}{c}4 \\
32 \\
64\end{array}$ & 0.003 \\
\hline $\begin{array}{c}\text { Medications } \\
\text { ACE inhibitors } \\
\text { Beta blockers } \\
\text { Aspirin } \\
\text { Clopidogrel } \\
\text { Amlodipine } \\
\text { Statins }\end{array}$ & $\begin{array}{l}100 \\
100 \\
67 \\
21 \\
26 \\
83\end{array}$ & $\begin{array}{c}100 \\
100 \\
70 \\
11 \\
31 \\
87\end{array}$ & 0.341 \\
\hline
\end{tabular}

As expected, the ferritin level was higher in G1 ( $\mathrm{p}=$ $0.001)$. Although differences were not significant in a level of diastolic $(p=0.078)$ and systolic pressure $(p=0.523)$, patients with anemia were more often hypertensive (65\%) compared to the others who were mainly normotensive $(p=0.001)$. Anemic patients significantly scored higher dyspnea $(p=0.003)$, fatigue $(p=0.038)$ and peripheral edema $(p=0.007)$. Majority of patients in G1 rated their adherence as low (42\%), and in G2 as high (41\%; $\mathrm{p}=0.005)$, (Table 2$)$.

Table 2. Clinical characteristics of the study participants Табела 2. Клиничке карактеристике пацијената у односу на статус анемије

\begin{tabular}{|c|c|c|c|}
\hline Variable & $\begin{array}{c}\text { Group } 1 \\
\%\end{array}$ & $\begin{array}{c}\text { Group } 2 \\
\%\end{array}$ & $\mathbf{p}$ \\
\hline $\begin{array}{l}\text { Systolic blood pressure } \\
\quad<140 \mathrm{mmHg} \\
>140 \mathrm{mmHg}\end{array}$ & $\begin{array}{l}62 \\
38\end{array}$ & $\begin{array}{l}72 \\
28\end{array}$ & 0.523 \\
\hline $\begin{array}{c}\text { Diastolic blood pressure } \\
<90 \mathrm{mmHg} \\
>90 \mathrm{mmHg}\end{array}$ & $\begin{array}{l}43 \\
57\end{array}$ & $\begin{array}{l}57 \\
43\end{array}$ & 0.078 \\
\hline $\begin{array}{l}\text { Blood pressure } \\
\text { normotensive } \\
\text { hypertensive }\end{array}$ & $\begin{array}{l}35 \\
65\end{array}$ & $\begin{array}{l}52 \\
48\end{array}$ & 0.001 \\
\hline $\begin{array}{c}\text { Rhythm disturbance } \\
\text { No } \\
\text { Yes }\end{array}$ & $\begin{array}{l}38 \\
62\end{array}$ & $\begin{array}{l}60 \\
40\end{array}$ & 0.001 \\
\hline $\begin{array}{c}\text { Left ventricular } \\
\text { hypertrophy } \\
\text { No } \\
\text { Yes } \\
\end{array}$ & $\begin{array}{l}28 \\
72\end{array}$ & $\begin{array}{l}62 \\
38\end{array}$ & 0.001 \\
\hline $\begin{array}{c}\text { ST segment elevation } \\
\text { No } \\
\text { Yes } \\
\end{array}$ & $\begin{array}{l}40 \\
60\end{array}$ & $\begin{array}{l}75 \\
25\end{array}$ & 0.001 \\
\hline $\begin{array}{c}\text { CRP } \mathbf{~ m g / l} \\
<1 \\
1-2 \\
>3\end{array}$ & $\begin{array}{c}9 \\
19 \\
72\end{array}$ & $\begin{array}{c}5 \\
41 \\
54\end{array}$ & 0.043 \\
\hline $\begin{array}{c}\text { Ferritin, } \mu \mathrm{g} / \mathrm{ml} \\
<100 />100\end{array}$ & $\begin{array}{l}18 \\
82 \\
\end{array}$ & $\begin{array}{l}87 \\
13 \\
\end{array}$ & 0.001 \\
\hline $\begin{array}{c}\text { Edema } \\
\text { No } \\
\text { Yes }\end{array}$ & $\begin{array}{l}18 \\
82\end{array}$ & $\begin{array}{l}49 \\
51\end{array}$ & 0.007 \\
\hline $\begin{array}{c}\text { Dyspnea } \\
\text { No } \\
\text { Yes }\end{array}$ & $\begin{array}{l}66 \\
34\end{array}$ & $\begin{array}{l}84 \\
16\end{array}$ & 0.003 \\
\hline $\begin{array}{c}\text { Fatigue } \\
\text { No } \\
\text { Yes }\end{array}$ & $\begin{array}{l}74 \\
26\end{array}$ & $\begin{array}{l}83 \\
17\end{array}$ & 0.038 \\
\hline $\begin{array}{l}\text { Adherence } \\
\text { High } \\
\text { Intermediate } \\
\text { Low }\end{array}$ & $\begin{array}{l}23 \\
35 \\
42\end{array}$ & $\begin{array}{l}41 \\
31 \\
28\end{array}$ & 0.005 \\
\hline
\end{tabular}


Distribution of respondents according to illness perception is presented in Table 3. Study participants in G1 scored higher seriousness of illness $(\mathrm{p}=0.041)$, duration of disease $(\mathrm{p}=0.039)$, loss of control $(\mathrm{p}=0.024)$, lack of treatment usefulness $(p=0.001)$, number of experienced symptoms $(p=0.001)$ and being worried about the disease $(\mathrm{p}=0.029)$, (Table 3 ).

Table 3. Participents distribution according to the illness perception

Табела 3. Расподјела испитаника према перцепцији болести

\begin{tabular}{|c|c|c|c|}
\hline Item & $\begin{array}{c}\text { Group } 1 \\
\%\end{array}$ & $\begin{array}{c}\text { Group } 2 \\
\%\end{array}$ & p \\
\hline $\begin{array}{l}\text { How much does the disease } \\
\text { affect your life? } \\
\text { Doesn`t affect } \\
\text { Affects } \\
\text { Seriously affects }\end{array}$ & $\begin{array}{c}2 \\
20 \\
78\end{array}$ & $\begin{array}{c}7 \\
29 \\
61\end{array}$ & 0.041 \\
\hline $\begin{array}{c}\text { How long do you think your } \\
\text { disease will last? } \\
\text { Forever } \\
\text { Some time } \\
\text { A short time }\end{array}$ & $\begin{array}{l}52 \\
26 \\
22\end{array}$ & $\begin{array}{l}32 \\
31 \\
37\end{array}$ & 0.039 \\
\hline $\begin{array}{l}\text { How much control have you } \\
\text { got over your disease? } \\
\text { Exceptional } \\
\text { Partial } \\
\text { Without control }\end{array}$ & $\begin{array}{l}13 \\
30 \\
56\end{array}$ & $\begin{array}{l}27 \\
45 \\
27\end{array}$ & 0.024 \\
\hline $\begin{array}{c}\text { How helpful is the treatment } \\
\text { for your disease? } \\
\text { Not too much } \\
\text { Partially useful } \\
\text { Useful }\end{array}$ & $\begin{array}{l}19 \\
40 \\
41\end{array}$ & $\begin{array}{c}5 \\
22 \\
73\end{array}$ & 0.001 \\
\hline $\begin{array}{l}\text { How many symptoms have } \\
\text { you got? } \\
\text { I have no serious symptoms } \\
\text { I have plenty of symptoms } \\
\text { All symptoms }\end{array}$ & $\begin{array}{l}10 \\
17 \\
73\end{array}$ & $\begin{array}{l}38 \\
29 \\
33\end{array}$ & 0.001 \\
\hline $\begin{array}{c}\text { How worried are you about } \\
\text { your disease? } \\
\text { Not too worried } \\
\text { Partially worried } \\
\text { Worried }\end{array}$ & $\begin{array}{l}27 \\
38 \\
35\end{array}$ & $\begin{array}{l}13 \\
18 \\
68\end{array}$ & 0.029 \\
\hline $\begin{array}{l}\text { How well do you understand } \\
\text { your disease? } \\
\text { I do not understand everything } \\
\text { Partially understand } \\
\text { I understand everything very } \\
\text { clearly }\end{array}$ & $\begin{array}{l}38 \\
35 \\
27\end{array}$ & $\begin{array}{l}21 \\
27 \\
52\end{array}$ & 0.017 \\
\hline $\begin{array}{l}\text { Does your illness affect you } \\
\text { emotionally? } \\
\text { It does not affect emotionally } \\
\text { It affects emotionally } \\
\text { Exceptional emotional } \\
\text { affection } \\
\end{array}$ & $\begin{array}{l}22 \\
34 \\
43\end{array}$ & $\begin{array}{l}11 \\
25 \\
64\end{array}$ & 0.013 \\
\hline
\end{tabular}

Negative, statistically significant correlations were found between the understanding of disease and adherence in $\mathrm{G} 1(\mathrm{r}=-0.355, \mathrm{p}=0.001)$ and $\mathrm{G} 2(\mathrm{r}=-0.236, \mathrm{p}=0.022)$. The participants who worried more about their illness had lower treatment adherence in $\mathrm{G} 2(\mathrm{r}=-0,206, \mathrm{p}=0,36)$, (Table 4).

Table 4. The relationship between the illness perception and the treatment adherence

Табела 4. Повезаност перцепције болести и сарадљивости

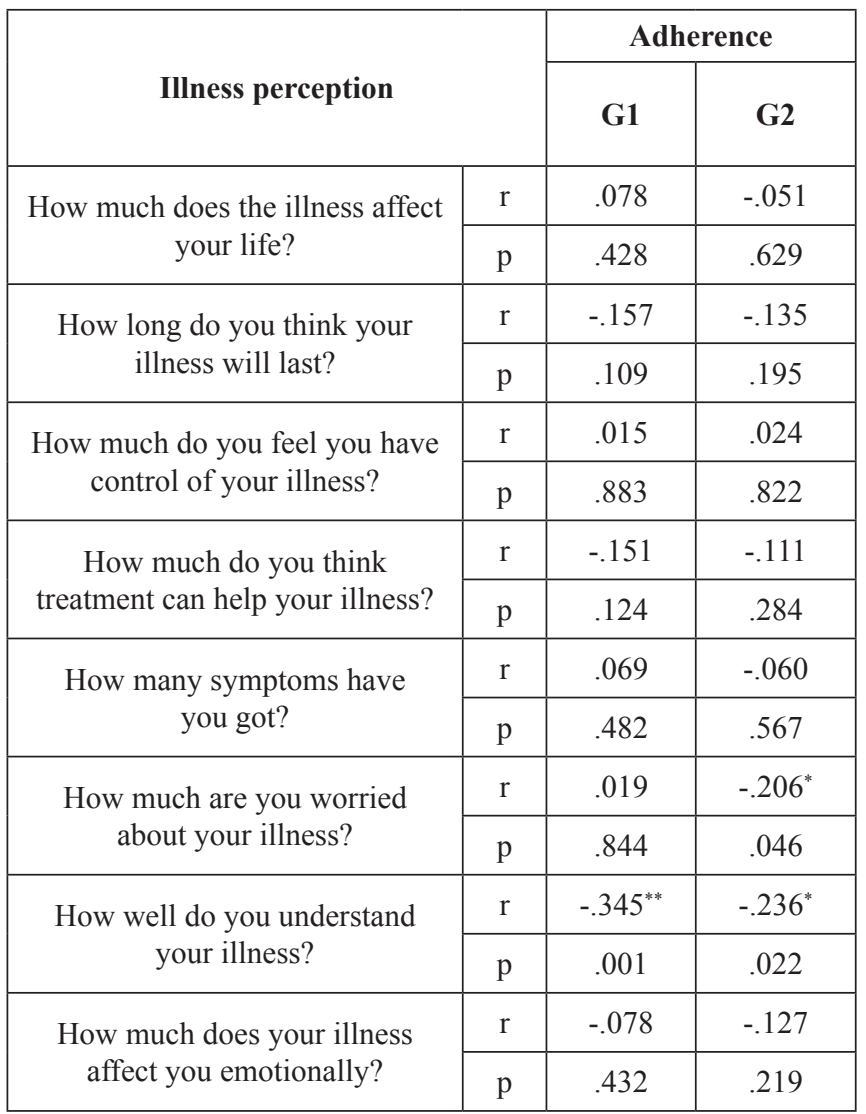

${ }^{*} \mathrm{p}<0.05, * * \mathrm{p}<0.01$

The study participants feeling less worried by their disease and whose treatment adherence was high had shorter length of hospitalization ( $\mathrm{p}=0.001)$, duration of disease $(p=0.001: p=0.012)$, lower CRP-level $(p=0.02 ; p=0.006)$, less edema $(\mathrm{p}=0.001)$ and rhythm disturbances $(\mathrm{p}=0.002$ : $\mathrm{p}=0.001)$, higher erythrocyte count $(\mathrm{p}=0.001)$, higher iron level $(p=0.001)$, higher hemoglobin value $(p=0.001)$, $\operatorname{MCV}(\mathrm{p}=0.001), \operatorname{TIBC}(\mathrm{p}=0.001)$, ferritin and less dyspnea $(\mathrm{p}=0.032: \mathrm{p}=0.001)$. Linear relationship between adherence/ illness perception and fatigue level was not found. Correlations between adherence/illness perception and other treatment outcomes, such as anthropometric measurements and diastolic/systolic arterial pressure were not statistically significant ( $>00.005)$, (Table 5). 
Table 5. The relationship between the treatment outcomes, treatment adherence and illness perception

Табела 5. Повезаност исхода третмана, сарадљивости и перцепције болести

\begin{tabular}{|c|c|c|c|}
\hline \multicolumn{2}{|l|}{ Treatment outcome } & Adherence & Perception \\
\hline \multirow{2}{*}{ Duration of the disease } & $\mathrm{r}$ & $-.177^{*}$ & $-.327^{* *}$ \\
\hline & $\mathrm{p}$ & .012 & .001 \\
\hline \multirow{2}{*}{ Length of hospitalization } & $\mathrm{r}$ & $-.238^{* *}$ & $-.395^{* *}$ \\
\hline & $\mathrm{p}$ & .001 & .001 \\
\hline \multirow{2}{*}{$\begin{array}{l}\text { Erythrocyte sedimentation } \\
\text { rate }(\mathrm{mm} / \mathrm{h})\end{array}$} & $\mathrm{r}$ & $-.213^{* *}$ & $-.258^{* *}$ \\
\hline & $\mathrm{p}$ & .003 & .001 \\
\hline \multirow{2}{*}{$\mathrm{C}$ reactive protein (mg/l.) } & $\mathrm{r}$ & $-.194^{* *}$ & $-.163^{*}$ \\
\hline & $\mathrm{p}$ & .006 & .021 \\
\hline \multirow{2}{*}{$\begin{array}{l}\text { Erythrocyte count } \\
\quad\left(1 \times 10^{12} / \mathrm{L}\right)\end{array}$} & $\mathrm{r}$ & $.240^{* *}$ & $.678^{* *}$ \\
\hline & $\mathrm{p}$ & .001 & .001 \\
\hline \multirow{2}{*}{ Hemoglobin $(\mathrm{g} / \mathrm{L})$} & $\mathrm{r}$ & $.342^{* *}$ & $.716^{* *}$ \\
\hline & $\mathrm{p}$ & .001 & .001 \\
\hline \multirow{2}{*}{$\operatorname{MCV}(f l)$} & $\mathrm{r}$ & $.235^{* *}$ & $.686^{* *}$ \\
\hline & $\mathrm{p}$ & .001 & .001 \\
\hline \multirow{2}{*}{ Hematocrit (L/L) } & $\mathrm{r}$ & $.304^{* *}$ & $.666^{* *}$ \\
\hline & $\mathrm{p}$ & .001 & .001 \\
\hline \multirow{2}{*}{ Iron $(\mu \mathrm{mol} / 1)$} & $\mathrm{r}$ & $.226^{* *}$ & $.708^{* *}$ \\
\hline & $\mathrm{p}$ & .001 & .001 \\
\hline \multirow{2}{*}{ TIBC $(\mu \mathrm{mol} / \mathrm{L})$} & $\mathrm{r}$ & $-.217^{* *}$ & $-.619^{* *}$ \\
\hline & $\mathrm{p}$ & .002 & .001 \\
\hline \multirow{2}{*}{ Ferritin (ng/ml) } & $\mathrm{r}$ & $.198^{* *}$ & $.561^{* *}$ \\
\hline & $\mathrm{p}$ & .005 & .001 \\
\hline \multirow{2}{*}{ Transferrin (\%) } & $\mathrm{r}$ & $.245^{* *}$ & $.726^{* *}$ \\
\hline & $\mathrm{p}$ & .001 & .001 \\
\hline \multirow{2}{*}{ Waist circumference } & $\mathrm{r}$ & -.015 & .029 \\
\hline & $\mathrm{p}$ & .828 & .682 \\
\hline \multirow{2}{*}{ BMI } & $\mathrm{r}$ & .021 & .015 \\
\hline & $\mathrm{p}$ & .770 & .829 \\
\hline \multirow{2}{*}{ Systolic blood pressure } & $\mathrm{r}$ & -.030 & -.026 \\
\hline & $\mathrm{p}$ & .672 & .717 \\
\hline \multirow{2}{*}{ Diastolic blood pressure } & $\mathrm{r}$ & -.097 & -.130 \\
\hline & $\mathrm{p}$ & .170 & .067 \\
\hline \multirow{2}{*}{ Holter 24 hours } & $\mathrm{r}$ & $-.229^{* *}$ & $-.215^{* *}$ \\
\hline & $\mathrm{p}$ & .001 & .002 \\
\hline \multirow{2}{*}{ Edema } & $\mathrm{r}$ & $-.203^{* *}$ & $-.252^{* *}$ \\
\hline & $\mathrm{p}$ & .001 & .001 \\
\hline \multirow{2}{*}{ Fatigue } & $\mathrm{r}$ & -.015 & .029 \\
\hline & $\mathrm{p}$ & .828 & .682 \\
\hline \multirow{2}{*}{ Dyspnea } & $\mathrm{r}$ & $-.066^{* *}$ & $-.295^{* *}$ \\
\hline & $\mathrm{p}$ & .032 & .001 \\
\hline
\end{tabular}

" $p<0,05 ; " \mathrm{p}<0,01$

\section{Discussion}

The current study found a relationship between treatment outcomes and treatment adherence in addition to illness perception among patients with heart failure. The study participants with associated anemia felt more endangered by their disease and were less adherent to the treatment compared to individuals without anemia. Our findings corroborate the results of previous studies ${ }^{3,5,12}$.

Although the difference between the values of diastolic and systolic arterial pressure individually was not found between the participants in regards to anemia, anemic patients were more often hypertensive compared to non-anemic. Joseph et al. detected higher blood pressure values in HR patients with anemia ${ }^{13}$, while recent Korean study showed no association between anemia and hypertension ${ }^{14}$ when adjusted to body mass index and waist circumference. Correlation between how patients perceive their illness or adhere to medication and hypertension was not statistically significant. However, the results may have been influenced by other risk factors that were not analyzed in the present study.

In line with previous research, anemic patients experienced fatigue, dyspnea, and edema more frequently compared to participants in G2, and it added to the general symptomatic status of the individuals ${ }^{15}$. Several groups of medications used to treat HR, angiotensin-converting inhibitors and betablockers may have increased the risk of anemia by inhibiting the hematopoietic activity or decreasing hemoglobin level. Anemia further decreases oxygen delivery and worsens dyspnea and fatigue ${ }^{16}$. Patients who considered dyspnea alarming and had edema, perceived their illness worse and were less adherent to the recommended treatment.

Anemic patients reported a strong impact of illness on their lives and poorly controlled, incurable disease. Earlier research showed that stronger illness perception leads to better control over disease, and hence, more effective strategies for overcoming the disease or ability to cope withchallenges posed by the chronic disease. It also detected that people with higher severity of the disease also express greater concern about the disease and consider that the disease has a major impact on their life ${ }^{17}$. The length of hospitalizations and the duration of disease were in negative correlation with a perception of the disease and treatment adherence in the current study, which could be explained by the fact that people are not passive objects affected by the disease, but that beliefs about the disease affect their perception ${ }^{18}$. The everity of the disease is significantly related to the perception of chronic diseases and the negative impact on the disease on the emotional state ${ }^{19}$. Morgan et al. found that emotions and mood are integral aspects of illness perception ${ }^{20}$. Disease understanding was the only domain of illness perception in correlation with patients' adherence. By exploring maladaptive illness perceptions among the patients with HR and anemia, patients' wellbeing, treatment outcomes and quality of life could be influenced and improved ${ }^{12}$.

Participants in group one had significantly lower adherence compared to participants from group two. Inadequate use of medicines by patients with cardiovascular disease is a common occurrance in physicians` daily practice ${ }^{21}$. Appropri- 
ate intervention, such as home-based, high-intensity interval training or multimodal approaches with interactive feedback could improve the adherence to pharmacological therapy and accompanying lifestyle recommendations can be improved by means of appropriate interventions ${ }^{21-24}$. Exploring patients' views, ideas, and expectations, or introducing the discussion between health care provider and patient during the medical encounter which is not purely medical, has a positive impact on illness perception and helps patients develop an identity and personal control over the treatment process ${ }^{25}$.

Study participants with anemia had higher CRP levels compared to the participants from group 2. The lower the CRP levels, the higher the adherence and illness perception was more positive. Higher levels of CRP are common finding among individuals with more severe heart failure, increasing the risk of mortality and morbidity. The majority of epidemiological studies showed a significant correlation between increased CRP and atherosclerosis, and the risk of repeated cardiovascular events in patients with chronic heart failure ${ }^{26}$. Data on the impact of sideropenic anemia treatment on CRP values in patients with heart failure are limited.

\section{Conclusion}

The illness perception and treatment adherence have a significant impact on treatment outcomes of heart failure. Comorbidities, such as anemia, contribute to the patients' perception of their disease and influence their adherence. Treating anemia and iron deficiency could reduce disease symptoms, which significantly impair the patient's self-perceived health status.

\section{Conflicts of interests}

There is no financial, personal, or academic conflict of interest. 
Биљана М. Букић', Маја Н. Рачић²,

Јелена Р. Павловић', Биљана П. Мијовић²

Здравствени центар Бањалука, Босна и Херцеговина ${ }^{1}$ Медицински факултет Фоча, Универзитет у Источном Сарајеву, Босна и Херцеговина ${ }^{2}$

\section{Перцепција болести и адхерентност код пацијената са хроничном срчаном инсуфицијенцијом и сидеропенијском анемијом}

\section{Сажетак}

Кључне речи:

срчана инсуфицијенција, сидеропенијска анемија, перцепција болести, адхерентност.
Циљ рада. Главни циљ ове студије био је испитати да ли перцепција болести и адхерентност у процесу лијечења утичу на резултате лијечења срчане инсуфицијенције. Други циљ ове студије био је утврдити да ли постоје разлике у перцепцији и адхерентности код пацијената.

Метод. Студија пресјека је била проведена 2015 године. Једна група се састојала од 100 пацијената са срчаном инсуфицијенцијом удруженом са сидеропенијском анемијом, а друга група од 100 пацијената без анемије. За демографске податке коришћен је стандардизовани упитник - Кратки упитник о перцепцији болести ради мјерења пацијента и модификована Клиничка скала за процјену адхерентности пацијента.

Резултати. Већина испитаника у првој групи су биле жене - 63\%, док је у другој групи било 58\% мушкараца и 42\% жена. Испитаници из прве групе су имали статистички значајно нижу адхерентност у односу на испитанике из друге групе $(\chi 2=23,28 ; p=0,05)$. Утврђена је значајна разлика између група испитаника у поређењу са перцепцијом контроле болести $(\chi 2=18,03 ; p=0,05)$

Закључак. Перцепција болести и адхерентност третмана имају значајан утицај на перцепцију њихове болести, као и утицај на њихово придржавање. 


\section{References}

\section{Литература}

1. Health and economic burden of hospitalizations for heart failure. Lessons learned from hospitalized heart failure registries. J Am Coll Cardiol 2014; 63:1123-1133.

2. Mitchell PM, Al-Janabi H, Richardson J, Iezzi A, Coast J. The relative impacts of disease on health status and capability wellbeing: a multi-country study. Plos One 2015;10:e143590.

3. Enjuanes C, Klip IT, Bruguera J, Cladellas $\mathrm{M}$, Ponikowski $\mathrm{P}$, BanasiakW, van Veldhuisen DJ, van der Meer P, Jankowska EA, Comín-Colet J. Iron deficiency and health-related quality of life in chronic heart failure: results frommulticentrice European study. Int J Cardiol 2014;174:268-275.

4. Djukic B, Racic M, Mijovic B, Ivkovic N Health-related quality of life in outpatients with chronic heart failure associated with sideropenic anemia. Journal of Public Health: From Theory to Practice 2018;26:631-638.

5. Comín-Colet J, Enjuanes C, González G, Torrens A, Cladellas M, Meroño O, Ribas N, Ruiz S, Gómez M, Verdú JM, Bruguera J. Iron deficiency is a key determinant of health-related quality of life in patients with chronic heart failure regardless of anaemia status. Eur J Heart Fail 2013;15:1164-1172.

6. Tim Goodnough L, Comin-Colet J, LealNoval S, Ozawa S, Takere J,Henry D, Javidroozi M, Hohmuth B, Bisbe E, Gross I, Shander A. Management of anemia in patients with congestive heart failure. Am J Hematol 2017: 92:88-93.

7. Broadbent E, Wilkes C, Koschwanez $\mathrm{H}$, Weinman J, Norton S, Petrie KJ. A systematic review and meta-analysis of the Brief Illness Perception Questionnaire. Psychol Health. 2015;30(11):1361-85.

8. Saarti S, Hajj A, Karam L, Jabbour H, Sarkis A, El Osta N, Rabbaa Khabbaz L. Association between adherence, treatment satisfaction and illness perception in hypertensive patients. J Hum Hypertens. 2016;30(5):341.

9. Weinman JA. The illness perception questionnaire: a new measure for assessing the cognitive representation of illness. Psychol Health. 1996;11:431.

10. Kemp R, Hayward P, Applewhaite G, Everitt B, David A. Compliance therapy in psychotic patients:randomized controlled trial. BMJ 1996;312(7027): 345-9.
11. Kemp R, Kirov G, Everitt B, Hayward P, David A. Randomised controlled trial of compliance therapy. 18-month follow-up. Br J Psychiatry 1998;172:413-9.

12. Timmermans I, Verseeg H, Meine M, Pedersen SS, Denollet J. Illness perception in patients with heart failure and an implantable cardioverter defibrillator: dimensional structure, validity, and correlates of the Brief Illness Perception Questionnaire in Dutch, French and German patients. J of Psychosomatic Research 2017;97:1-8

13. Josep CC, Cristina E, Gina G, Ainhoa T, Mercè $\mathrm{C}$, Oona $\mathrm{M}$, et al. Iron deficiency is a key determinant of health-related quality of life in patients with chronic heart failure regardless of anaemia status. Eur J Heart Fail 2013; 15(10): 1164-1172.

14. Yoon H, Lee JH, Kim GS, Kim YJ, Hwang EYPark CE, et al. The relationship between anemia and pulse pressure and hypertension: The Korea National Health and Nutrition Examination Survey 2010-2012. Clinical and Experimental hypertension 2018;10:1-6.

15. Doehner W, von Haehling S, Anker SD. Anaemia predicts health related quality of life in heart failure patients. Int J Cardiol 2013;162:67-68.

16. Beverborg GN, van Veldhuisen DJ, van der Meer P. Anemia in heart failure. Still relevant. JAACC: Heart failure 2017; 65 (11):79-80.

17. Fortune DG, Richards HL, Griffiths C.E.M. \& Main CJ. Psychological stress, distress and disability in patients with psoriasis: consensus and variation in the contribution of illness perceptions, coping and alexithymia. British Journal of Clinical Psychology 2002;41:157-74.

18. Wahl AK, Moum T, Robinson HS, Langeland E, Larsen MH, Krogstad AL. Psoriasis patients' knowledge about the disease and treatments. Acta Derm Venereol 2013;93:XX-XX

19. Plotka A, Patients' knowledge of heart failure and their perception of the disease. Patient Preference and Adherence 2017; 11:1459-1467

20. Morgan K, Villiers-Tuthill A, Barker M, McGee $\mathrm{H}$. The contribution of illness perception to psychological distress in heart failure patients. BMC Psychology. 2014;2(1):50.
21. Unverzagt S, Meyer G, Mittmann S, Samos FA, Unverzagt M, Prondzinsky R. Improving Treatment Adherence in Heart Failure. Dtsch Arztebl Int. 2016;113(25):423-23.

22. Dolansky MA, Schaefer JT, Hawkins MA, et al. The association between cognitive function and objective adherence to dietary sodium guidelines in patients with heart failure. Patient Prefer Adherence. 2016;10:233-241.

23. Ulbrich AZ, Angarten VG, Netto AS, et al. Comparative effects of high intensity interval training versus moderate intensity continuous training on quality of life in patients with heartfailure: study protocol for a randomized controlled trial. Clin Trials Regul Sci Cardiol. 2016;13:21-28.

24. Safiyari-Hafizi H, Taunton J, Ignaszewski A, Warburton DE. The health benefits of a 12-week home-based interval training cardiac rehabilitation program in patients with heart failure. Can J Cardiol. 2016;32(4):561-567.

25. Young L, Hertzog M, Barnason S. Effects of a home-based activation intervention on self-management adherence and readmission in rural heart failure patients. the PATCH randomized controlled trial. BMC Cardiovasc Disord. 2016;16(1):176

26. Račić M, Kusmuk S, Mašić S, Ivković $\mathrm{N}$, Joksimović V, Matović J. Impact of the physician-patient relationship on the treatment outcomes of arterial hypertension. Opsta medicina 2017;23 (1-2):1-8.

27. Amit Kumar Shrivastava, Harsh Vardhan Singh, Arun Raizada, Sanjeev Kumar Singh. Egiptian Heart Journal 2015; 67(2): 89-97.

Примљен • Received: 